Annals of the Rheumatic Diseases, 1981, 40, 628-629

\title{
Viewpoint
}

\section{A new direction for the rheumatology nurse}

Rheumatology as a nursing specialty has developed circumstantially in various ways, but not through research or by sharing of experience and skills. This does not imply that standards of nursing care are inadequate but indicates the need for a less haphazard method for building up knowledge. Advances in medicine and surgery in the field of rheumatology have greatly broadened the role of nurses. Today they are concerned with the patient's past, present, and future to an extent which is often not generally realised by other professionals in the Health Service.

The complexities of the rheumatic diseases, and the consequent diverse problems for patients and their families, demand that the nurse is required constantly to support and educate the patient. Thus she must provide an atmosphere of trust in which the patient is able to discuss problems and anxieties. At the same time the nurse must coordinate the various types of treatment which have been prescribed and ensure that a reasonable degree of compliance is achieved. Does the patient have sufficient information about medication? Will the programme of exercises be continued by the patient after discharge from hospital? To accomplish all this the nurse should expect and be provided with an education which makes it possible.

The seeds have thus been sown for our now established Rheumatology Nurses' Forum. Many of us realised that we were working in isolation, both from one another and also from other organisations involved in the care of patients suffering from rheumatic diseases. When Sister Vicky Stephenson (ward sister, Carlisle City Ceneral Hospital) and I met for the first time it was a great relief to us both to realise we shared these anxieties. Apparently it had been highlighted further for Vicky when she met with other nurses, particularly ward sisters, during a scholarship study tour in Englard. It was obvious that as many of us as possible should meet to discuss our anxieties and needs and share our gathered knowledge and ideas.

Initially 120 ward sisters were contacted by letter to confirm the feelings already individually airedthat we needed to unite ourselves as a 'forum'.
Ninety-six nurses replied both from hospital and from community areas, and, of these, 45 attended $\vec{\circ}$ the inaugural meeting, which was held at Manchester $\overrightarrow{\vec{\omega}}$ Royal Infirmary in March 1981. We were delighted $\stackrel{\omega}{\omega}$ with this response, particularly in view of the fact that many of those who attended paid for their own expenses. The forum has been established under the auspices of the Royal College of Nursing, and $\%$ Miss M Lee (professional officer, Association of $N_{\infty}$ Nursing Practice) was our chairman for the day at 0 Manchester.

The emphasis at the conference was naturally on $\vec{\nabla}$ education, with 4 speakers participating. The opening speaker, $\mathrm{Mr} \mathrm{P}$ Callaghan, senior tutor, $\frac{\mathbb{D}}{3}$ postbasic education, Stebbing Hill Hospital, Stockport, described the Joint Board of Clinical Nursing Studies' courses in rheumatic disease; the $\vec{\otimes}$ are courses of 6 months' duration available for bot. State-registered and State-enrolled nurses. I was the able to show a slide/tape programme which we had made on our ward at Charing Cross Hospital illustrating the care of the patient with rheumatoid arthritis while in hospital; I described how the idea $\stackrel{\odot}{\triangle}$ for the programme came about and how it was made. In the afternoon Miss $\mathbf{R}$ Paxton, ward sister, $\frac{0}{3}$ Princess Margaret Rose Hospital, Edinburgh, and Mrs S Hughes, ward sister, Writhington Hospital, Lancashire, spoke enthusiastically about the multidisciplinary courses which they had helped to produce in their respective hospitals.

In discussions following the inaugural meeting we now feel that there should be 3 types of postbasic $>$ education available to nurses: (a) Study days which will serve as updating sessions for any nurse wishing to attend. (b) Joint Board of Clinical Nursing $\%$ Studies' short courses of 2-4 weeks' duration leading $N$ to a certificate of attendance; this course would be $N$ suitable for nurses who already have quite a wealth 0 of experience. (c) Joint Board of Clinical Nursing $\underset{\bullet}{0}$

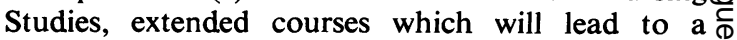
certificate of competence. Emphasis must still be $\stackrel{\mathscr{P}}{\rightarrow}$ placed on the value of practical training in the ward $\square$ for all grades of nurses, with special care that the trained staff are not neglected. 
The aims of our forum are to advance the skills and knowledge of the rheumatology nurse and thereby to improve all aspects of patient care. The forum will act as a pressure group at both national and international levels and will serve to forge links with other health professional organisations.

The seeds were sown on obviously fertile ground. Our Rheumatology Nurses' Forum quickly came

\section{Obituary}

\section{Carl M. Pearson, MD}

With the death of Dr Carl M. Pearson on 31 May 1981 the world of rheumatology lost one of its most eminent scholars. Dr Pearson, who was professor of medicine and director of the Division of Rheumatology in the Department of Medicine at the University of California in Los Angeles, was an international authority in not one but two separate provinces of medicine-rheumatology and neuromuscular disorders. In the latter his work led to the recognition and elucidation of a host of new myopathies. He was acknowledged to be our ranking expert on polymyositis and related forms of inflammatory muscle disease.

Dr Pearson was the coauthor or editor of 10 books and 300 scientific reports. In the realm of rheumatology he was renowned for the depth and breadth of his interests, which led to important contributions to our understanding of the clinical manifestations, pathological features, pathogenesis, and treatment of a wide variety of diseases. Particularly noteworthy were his work on adjuvant arthritis and other forms into being. We look forward to our future with much excitement and interest and a great sense of relief that we are now together and no longer in isolation.

SALLY CHESSON Ward Sister

Charing Cross Hospital, London W6. of experimental joint disease and his studies of dermatomyositis and polymyositis, relapsing polychondritis, ankylosing spondylitis, Farber's disease, Wegener's granulomatosis, and the place of immunosuppressive therapy in rheumatoid arthritis and other connective tissue diseases. There is no sphere of rheumatology which did not benefit from his attention.

Dr Pearson achieved positions of leadership in several professional organisations and served as president of the American Rheumatism Association in 1977-8. In 1980 he was named a Distinguished Professor of Medicine, a rare honour conferred by the University of California on 'scholars and teachers of the highest distinction, whose work has been internationally recognised and acclaimed.' $\mathrm{He}$ was much sought after as a lecturer and travelled widely. More than this, he was a master builder who put together one of the strongest and most accomplished rheumatology units in the world. He will be sorely missed.

G.P.R.

\section{5th European Immunology Meeting}

The 5th European Immunology Meeting will be held in Istanbul, Turkey, on 1-4 June 1982. Details from Dr Asuman Ủ. Müftüoglu, Nisbetiye Caddesi 2, Etiler, Istanbul, Turkey.
The Third International Congress of Thermology will be held in Bath, England, on 29 March-2 April 1982. Details from the Congress Secretariat. Martlet Conference Services, The Manor House, Southwick, Brighton, West Sussex BN4 4UB, England. 